\title{
Coastal rehabilitation through the implementation of government policy: Case study in Karawang Regency, West Java, Indonesia
}

\author{
Medi Nopiana ${ }^{1,3 *}$; Fredinan Yulianda²; Sulistiono²; Achmad Fahrudin ${ }^{2,4}$ \\ 1) Study Program for Coastal and Marine Resources Management, Graduated Program, \\ IPB University, Indonesia \\ 2) Department of Aquatic Resources Management, IPB University, Indonesia \\ 3) Faculty of Economics and Business, University of Singaperbangsa Karawang, \\ Indonesia \\ 4) Center for Coastal and Marine Resources Studies, IPB University, Indonesia \\ *To whom correspondence should be addressed. E-mail: medinopiana@yahoo.co.id
}

\begin{abstract}
Damage on the coastal area of Karawang Regency requires improvement efforts through the implementation of several government policies. However, modification of the policy developed to manage natural resources in the sea was one of the causes of non-optimal role of the government in rehabilitating coastal areas. This study aims to analyze the effectiveness of implemented regency government policies in achieving successful coastal rehabilitation. The data obtained were analyzed using descriptive analysis with a quantitative approach. The results shows the capacity of the Karawang Regency Government was still low in supporting the successful implementation of coastal rehabilitation policies. The Karawang Regency Government needs to collaborate with other stakeholders, redistribute employees, and encourage increase on education and training for staff.
\end{abstract}

Keywords: Coastal rehabilitation, Karawang Regency, Local government capacity

JEL Clasification: H11, H12, Q58, R11

\section{INTRODUCTION}

Damage due to erosion in the coastal region of Karawang regency has been at a very alarming level in recent times and has become of the most important issues in the management of the coastal areas which led to the introduction of the Regional Long-Term Development Plan (RPJPD) of Karawang Regency in 2005-2025 (Pemkab. Karawang, 2010). The erosion has been causing huge losses to the coastal communities and these include loss of pond land ( $\pm 352 \mathrm{ha}$ ), mangrove ( $\pm 82 \mathrm{ha}$ ), settlements $( \pm 12 \mathrm{ha})$, and others (Komarudin, 2013).

There have been several efforts towards controlling the erosion through coastal rehabilitation (DPUPR Kab. Karawang, 2016; DLHK Kab. Karawang, 2018), community adaptation through resettlement (DPRKP Kab. Karawang, 2018), and preparation of Detailed Engineering Design (DED) to plan coastal protection structure construction along coastal areas (Fauzie, 2017). The aspect of coastal rehabilitation includes the application of hard or soft structures and a combination of both methods. In general, the hard structure was in the form of revetment, breakwater, and beach belt construction using 
Elongated Geotextile Sack (KGM) technology while the soft ones include the planting of coastal vegetation like mangroves.

These rehabilitation efforts have been discovered not to be optimal due to the continuous occurrence of erosion in the areas. The efforts were later constrained through the enactment of Law Number 23 of 2014 on Regional Government which transferred the authority to manage matters related to maritime from the regency to the provincial government (Dapu, 2016; Djelantik, Sumerthayasa \& Suharta, 2016; Bachtiar \& Hans, 2016). This regulation provides the provincial government the authority to manage resources in the sea area as far as 12 nautical miles measured from the baseline towards the open sea and/or towards archipelagic waters (Adhayanto \& Adiputra, 2017). Therefore, the Karawang regency government no longer has full authority to implement coastal rehabilitation policies, meanwhile, based on the principle of accountability, it has the responsibility to administer its powers depending on its proximity to the range of impacts caused by environmental damage, including coastal erosion.

This has led to confusion in the implementation of the policies developed by the regency government because it requires simultaneous execution both in the coastal areas of land and sea for effectiveness but this has been restricted due to the fact the management of these two areas is under the control of two different levels of government. Moreover, it often led to varying perceptions and understandings of the laws and regulations which subsequently caused difficulties in synchronizing and coordinating the policies between the two levels of government.

Dunn (2003) stated that a policy system includes a reciprocal relationship between three elements, public policy, actors, and the environment. The role of the actors is very important in relation to the capacity possessed such as expertise, level of creativity, commitment, access and others (Febriani, 2012). Therefore, there was the need to research on the capacity of the Karawang Regency Government as one of the actors in the formulation and implementation of coastal rehabilitation policies.

Several works of research have been conducted on local government capacity in the implementation of public policies but none has been found on coastal rehabilitation policies. For example, Hidayat \& Asrida (2014) discussed the efforts towards overcoming coastal erosion without any attention on the capacity of the local governments while several other studies discussed the capacity that is not related to coastal rehabilitation policies such as those involving the management of conflicts over water resources (Rusmilyansari, Rosadi \& Apriansyah, 2014), mineral resources (Satria \& Anwar, 2018), urban development (Widyahantari \& Rudiarto, 2018), climate change impacts (Mukhlis, 2016), international relations (Mutia, Roisah \& Supriadhie, 2016; Fauzi, 2016), bureaucratic reform (Trisnantoro, 2011; Dewanti, Sarwono \& Makmur, 2013; Marliawati, 2013; Ningtyas, Ribawanto \& Hadi, 2014; Sari, Noor \& Prasetyo, 2014; Damayanti, 2016; Sahadia, Komba \& Basri, 2019), as well as regional economics, accounting, and finance (Sihombing, 2010; Iskandar, Bukit \& Yahya, 2013; Triastuti, 2013). The research purposed to analyze the capacity of the Karawang Regency Government for supporting the implementation of coastal rehabilitation policies.

\section{METHODS}

\section{Research time and location}

The research was conducted in November 2019 in several Regional Apparatus Organizations (OPD) of the Karawang Regency Government, West Java. Karawang Regency is in the northern part of West Java Province, geographically located between $5^{\circ} 56^{\prime}$ and $6^{\circ} 34^{\prime}$ southern latitude (S) and $107^{\circ} 02^{\prime}$ and $107^{\circ} 40^{\prime}$ in eastern longitude (E) 
(Figure 1). The total area of this regency is $1,753.27 \mathrm{~km}^{2}$ or 3.73 percent of the total area of West Java Province.

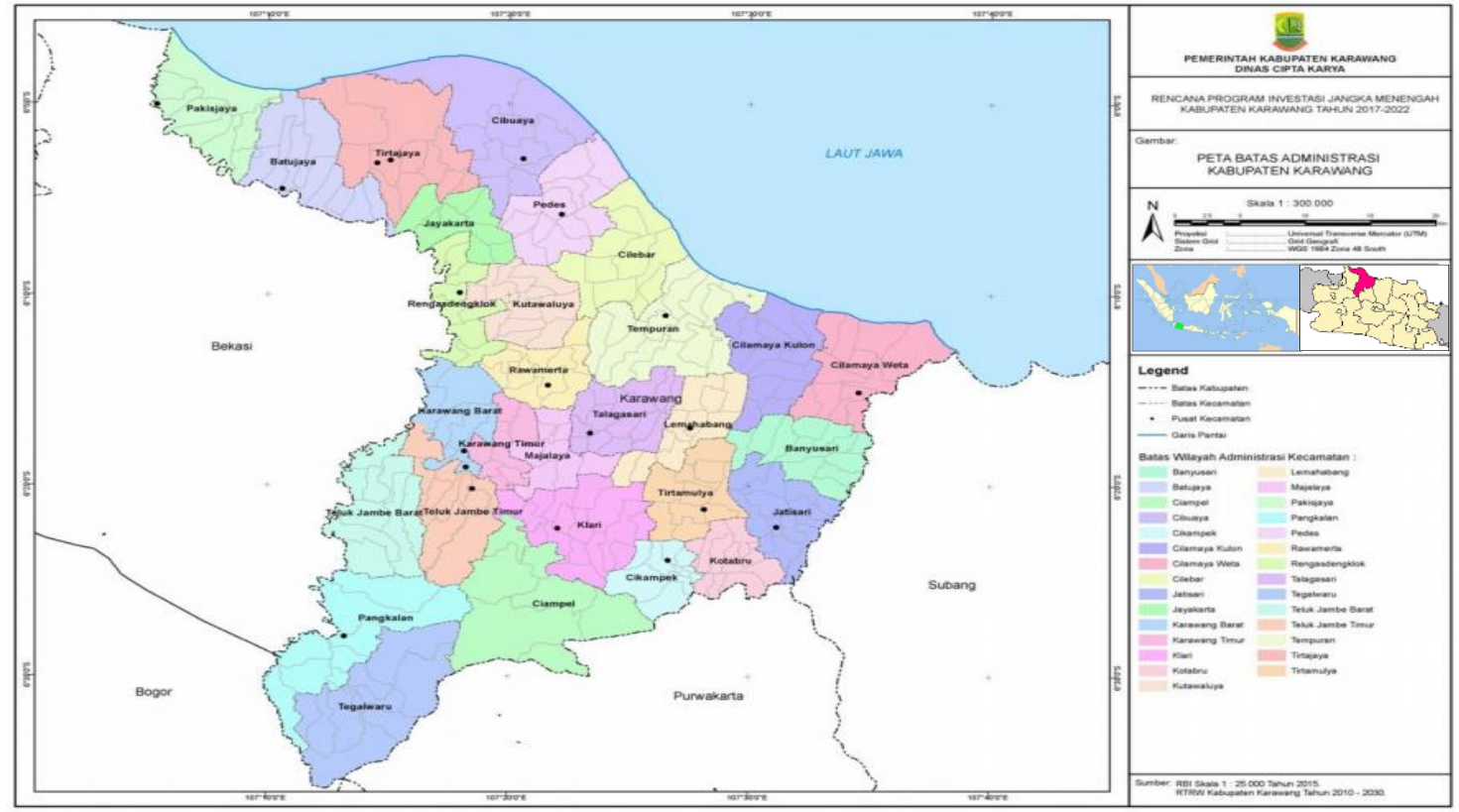

Source: DCK Kab. Karawang (2017)

Figure 1. Map of Karawang Regency administrative boundaries

\section{Data collection}

The research used primary and secondary data. Primary data obtained through collected from respondents through the use of questionnaires. Moreover, a probability sampling was used by combining cluster, multistage, and judgment sampling techniques while the number of samples was based on the procedure stated by Gay, Mills \& Airasian (2009) that the minimum for descriptive research should be 10 percent of the population (Alwi, 2012).

The sampling process was conducted in two stages and these involved determining the OPD sample with cluster and multistage techniques while the respondents were selected using judgment technique. There were 74 existing OPDs based on the data from the Karawang Regency Government in 2019 and the ones related to coastal erosion control policies totaled 23 while the ones related to coastal rehabilitation policies were 4 and they include the Offices of Environment and Hygiene, Fisheries, Public Works and Spatial Planning, and the Regional Development Planning Agency.

The data from the Regional Personnel and Human Resources Development Agency in 2019 showed the number of employees working in the fourth scope of the OPD was 255 with 101 as structural and functional officials related to the formulation of coastal rehabilitation policies and only 10 of these were selected as respondents. Moreover, some other information was collected through in-depth interviews with selected stakeholders in the Karawang Regency Government. Secondary data used in the research was obtained from the Central Bureau of Statistics, Regional Personnel and Human Resources Development Agency, and other OPDs and they include employee data by position and work unit, population, and others.

\section{Analysis}

The data were analyzed using descriptive analysis with a quantitative approach and systems thinking. Conceptually, this is a simple method mostly used to describe data 
collected (Nasution \& Usman, 2008) and the type used in this study was in the form of a survey which is also defined as an investigation conducted to obtain facts on existing symptoms (Nazir, 2014). Descriptive analysis with a quantitative approach calculated the average value of respondents' answers to various questions posed as applied Cahyadinata, Fahrudin, Sulistiono \& Kurnia (2019). Respondents' answers used a Likert Scale with three rating points (Table 1), namely: never/low/small/political (weight 1), rare/moderate/sufficient/economic (weight 2), and often/high/large/ecological (weight 3). The interval for each class is measured by the following criteria:

Table 1. Assessment criteria based on a Likert Scale

\begin{tabular}{cll}
\hline Class to & Score & Category \\
\hline 1 & $1,00-1,67$ & Never/low/small/political \\
2 & $1,68-2,33$ & rare/moderate/sufficient/economic \\
3 & $2,34-3,00$ & often/high/large/ecological \\
\hline
\end{tabular}

Systems thinking approach applied in this research is the causal loop diagram. The qualitative modeling illustrates the interrelationship between elements in a system (Setianto, 2016). The use of this approach aims to describe the causal link in the successful implementation of coastal rehabilitation policies. One of the main variables determining success is the capacity of the Karawang Regency Government. The factors of influence the capacity of the Karawang Regency Government in implementing coastal rehabilitation policies interact and depend on each other. Furthermore, it impacts on the effectiveness of overall coastal erosion control and the welfare of coastal communities.

\section{RESULTS AND DISCUSSION}

\section{Availability of human resources}

The majority of respondents represented by 80 percent reported the human resources available, in terms of quantity and quality, were inadequate to support coastal rehabilitation policies as shown in Figure 2.

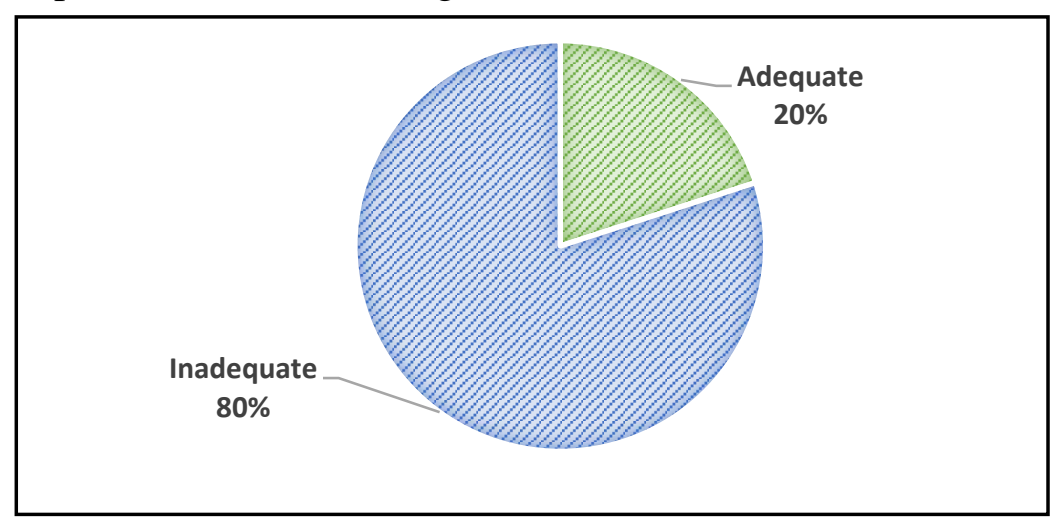

Figure 2. Availability of human resources Karawang Regency Government to support coastal rehabilitation policies

This was observed to be prominent among technical staff tasked with the responsibility of monitoring the condition of the coastline in coastal areas along $84.23 \mathrm{~km}$ as well as the lack of specific fields or sections focusing on the implementation of coastal rehabilitation policies but rather conducted only as part of the main duties and functions of several OPDs as shown in Table 2.

Another problem observed is the absence of officials with a background in oceanography despite its importance in understanding the physical and dynamic processes of seawater. The capabilities are also required to support coastal rehabilitation 
policies through research as well as the development and application of marine engineering and technology. Furthermore, it was discovered the Karawang regency government provides low support to the ideas proposed by the staff to achieve comprehensive coastal erosion control.

Table 2. Section names and number of personnel in various OPDs related

\begin{tabular}{lll}
\hline OPDs Related & Section/Subdivision Name & $\begin{array}{l}\text { Number of } \\
\text { personnel }\end{array}$ \\
\hline Environment and Hygiene Office & Section of Environmental Conservation & 1 person \\
Fisheries Office & Section of Fisherman Institutional & 1 person \\
Public Works and Spatial Planning & Section of Water Resources & 1 person \\
Office & Development and Enhancement & \\
Regional Development Planning & - Subdivision of Spatial Planning, & 1 person \\
Agency & Settlement and Environment & \\
& - Subdivision of Regional Infrastructure, & 1 person \\
& Transportation and Water Resources & \\
& - Subdivision of Regional Development & 1 person \\
& Financing & \\
\hline Total & & 6 persons \\
\hline
\end{tabular}

\section{Network and inter-institutional cooperation}

It is not possible for an institution to single-handedly complete development activities, therefore, a multi-functional, interdisciplinary and cross-sectoral interinstitutional work relationship is required. The results showed the involvement of other OPDs and the legislature in supporting coastal rehabilitation policies was in the rare category according to a score range of $1.43-2.71$ and an average of 1.87 while their support for the policy was found to be in the moderate category based on a score range of $1.71-2.57$ and an average of 2.00 .

This means even though other OPDs and legislature were rarely involved, they were quite instrumental in supporting coastal rehabilitation policies as observed in Table 3. This is due to the limitations in the main duties and functions of these OPDs, especially regarding the technical level of coastal rehabilitation implementation, which further leads to the low perception of their importance in achieving the objectives. For example, the Agriculture Office had never been involved and was found to have a small role in these policies despite the fact it is one of the sectors mostly affected by coastal erosion.

From the legislative perspective, the low perception of the district House of Representatives regarding the importance of their involvement in coastal rehabilitation policies was related to some political factors. It was based on the idea the policies are limited to small coastal communities with less electoral value as observed from the data provided by the Central Bureau of Statistics which showed the population of these areas in 2018 was 577,231 or only 24.71 percent of the total population of Karawang Regency which was 2,336,009.

The regency government was also discovered not to be focused and serious in supporting coastal rehabilitation policies as observed from the lack of institutions and working groups created specifically to handle its implementation and which are required to increase productivity and work effectiveness. However, other concerns include the contradiction between the working groups formed and others in different programs which subsequently led to ineffectiveness due to the use of the same personnel to achieve different objectives. 
Table 3. The Involvement and role of the Karawang Regency Government internal line for supporting the coastal rehabilitation policy

\begin{tabular}{|c|c|c|c|c|c|c|c|}
\hline \multirow{2}{*}{ No. } & \multirow{2}{*}{ Other OPDs } & \multicolumn{3}{|c|}{ Involvement (\%) } & \multicolumn{3}{|c|}{ Role $(\%)$} \\
\hline & & Often & Rare & Never & Large & Sufficient & Small \\
\hline \multirow[t]{2}{*}{1.} & Public Housing and Settlement & & & & & & \\
\hline & Area Office & 40 & 60 & 0 & 40 & 50 & 10 \\
\hline 2. & Agriculture Office & 20 & 0 & 80 & 0 & 10 & 90 \\
\hline 3. & Social Affairs Office & 10 & 20 & 70 & 20 & 50 & 30 \\
\hline 4. & Regional Secretariat & 30 & 70 & 0 & 50 & 50 & 0 \\
\hline 5. & Regional Disaster Relief Office & 20 & 80 & 0 & 40 & 60 & 0 \\
\hline \multirow[t]{2}{*}{6.} & Regional Financial and Asset & & & & & & \\
\hline & Management Agency & 30 & 0 & 70 & 30 & 50 & 20 \\
\hline \multirow[t]{2}{*}{7.} & Regency Regional & & & & & & \\
\hline & Representative Council & 20 & 40 & 40 & 10 & 50 & 40 \\
\hline
\end{tabular}

The coordination support to implement these policies within the regency government was found to be relatively low as observed with the score range of $1.00-1.50$ and an average of 1.40. This was discovered to be due to the lack of specific discussions related to the problem during meetings as well as specific budget allocations as shown in Table 4. Moreover, even though the coordination effort of regional heads was in the moderate category, their role as champions in the implementation of the policies was not optimal.

Table 4. Coordination support from internal regency

\begin{tabular}{clrrr}
\hline \multirow{2}{*}{ No. } & \multicolumn{2}{c}{ Support about } & \multicolumn{3}{c}{ Support intensity (\%) } \\
\cline { 3 - 5 } & & High & Moderate & Low \\
\hline 1. & Coordination support from the regional head & 0 & 80 & 20 \\
2. & Budget allocation support for coordination & 0 & 0 & 100 \\
\hline
\end{tabular}

Coordination problems between OPDs in supporting coastal rehabilitation policies also occurred in the Bengkalis District Government (Hidayat \& Asrida, 2014). The coordination effort had not run smoothly because communication between the OPDs had not established properly. Improved coordination between institutions was also one of the policy priorities for handling coastal erosion and abrasion in Cirebon and Ciamis Regency (Fitri, 2007).

The coordination capability of the regency government with external institutions was also in the moderate category as observed from the score range of $1.20-2.50$ and an average of 1.77 . This was associated with the relatively rare coordination intensity between the two stakeholders. However, Hogwood \& Gunn (1986) have reported disorganization as one of the causes of the failure to implement a public policy according to plan.

The Karawang Regency Government sought to coordinate by building networks and cooperation with the central government through the Coordinating Ministry of Maritime Affairs, the Ministry of Environment and Forestry, the Ministry of Maritime Affairs and Fisheries, and the Ministry of Public Works and Public Housing. This was observed in the support provided in accelerating the mangrove rehabilitation and coastal belt construction programs as well as the research on coastal protection models using floating breakwaters.

The intensity of cooperation with the provincial government in the context of coastal rehabilitation policies was found to be relatively rare as shown in Table 5. This means the government of the province has not proactively conducted initiatives to implement policies to rehabilitate the coastal areas despite its constitutional authority in 
the marine sector. Nevertheless, a coordination effort was observed with the West Java Provincial Government through the Ministry of Maritime Affairs and Fisheries in the form of facilitation and coordination of the mangrove rehabilitation program as well as the supervision and control of marine and fisheries resources.

Table 5. The intensity of coordination with external institutions

\begin{tabular}{clrrr}
\hline \multirow{2}{*}{ No. } & \multicolumn{1}{c}{ External institutions } & \multicolumn{3}{c}{ Intensity of coordination $(\%)$} \\
\cline { 3 - 5 } & & Often & Rare & Never \\
\hline 1. & Ministry of Marine Affairs and Fisheries & 20 & 50 & 30 \\
2. & Ministry of Public Works and Housing & 0 & 70 & 30 \\
3. & Ministry of Environment and Forestry & 10 & 50 & 40 \\
4. & Other ministries and institutions at the central & 10 & 80 & 10 \\
& government level & 20 & 50 & 30 \\
5. & Provincial government & 20 & 50 & 30 \\
6. & Private sector & 20 & 50 & 30 \\
7. & Colleges & 0 & 50 & 50 \\
8. & Research institutions & 50 & 10 & 40 \\
9. & Non-governmental organization & 0 & 10 & 90 \\
10. & Foreign institution & &
\end{tabular}

The networks and cooperation conducted by each OPD in relation to the central and provincial governments were often sectoral and less connected to other related offices partly due to the lack of discussion on these policies during meetings at the regional level. This has led to the absence of awareness by these related OPDs to inform each other about the problems faced and the follow-up results.

It was also discovered that the regional government cooperated with the private sector, universities, and non-governmental organizations to support the mangrove rehabilitation program through the use of Corporate Social Responsibility funds as observed with P.T. Toyota Motor Manufacturing Indonesia and P.T. Pertamina Hulu Energi Offshore North West Java. Besides, universities were also involved in research and community service activities as observed with the University of Singaperbangsa Karawang, Marine and Fisheries Polytechnic, and others while 15 non-governmental organizations with a total membership of 280 people participated in the mangrove rehabilitation program. It is also important to state that Nature Creative Group also helped in the management of the educational tourism of the Mangrove Restoration and Learning Center.

In line with these coordination capabilities, external institutional support for coastal rehabilitation policies was observed to be in the moderate category based on a score range of $1.00-2.33$ with an average of 1.75. This means there is a need for more support from all stakeholders, particularly the provincial government based on the low participation reported in Table 6 . This finding further reinforced the results of the intensity of coordination with the provincial government shown in Table 5.

Table 6. External institution support

\begin{tabular}{clrrr}
\hline \multirow{2}{*}{ No. } & \multicolumn{1}{c}{ External institution } & \multicolumn{3}{c}{ Support intensity $(\%)$} \\
\cline { 3 - 5 } & & High & Moderate & Low \\
\hline 1. & Ministry of Marine Affairs and Fisheries & 0 & 30 & 30 \\
2. & Ministry of Public Works and Housing & 0 & 40 & 60 \\
3. & Other ministries and institutions at the central & 60 & 40 \\
& government level & 0 & 40 & 60 \\
4. & Provincial government & 30 & 40 & 30 \\
5. & Private sector & 30 & 40 & 30 \\
6. & Non-governmental organizations & &
\end{tabular}




\section{Knowledge of coastal environmental conditions}

Social sensitivity is defined as the condition where an individual is encouraged to easily feel the changes in small things and this means someone with high social sensitivity would show a high sense of concern for others with ease (Mu'in, 2011). This was observed among the government officials with high knowledge of coastal environmental conditions based on the score range of $1.75-3.00$ with an average of 2.45. This indicates the government is well aware of the need to implement the policies as shown in Table 7 and this is in agreement with the findings of previous research that a policy environment greatly influences the successful implementation of public policies (Ekowati, 2009).

Table 7. Respondents' knowledge of the ecological and social conditions of coastal communities

\begin{tabular}{llrrr}
\hline \multirow{2}{*}{ No. } & \multicolumn{2}{c}{ Knowledge about } & \multicolumn{2}{c}{ Knowledge level (\%) } \\
\cline { 2 - 4 } & High & Moderate & Low \\
\hline 1. Potential of coastal resources & 60 & 20 & 20 \\
2. Impact of coastal erosion on: & & & \\
& - Ecological conditions & 80 & 20 & 0 \\
- Social conditions of the community & 40 & 20 & 40 \\
3. Frequency of visits to areas affected by coastal erosion & 60 & 20 & 20 \\
\hline
\end{tabular}

\section{Knowledge of relevant laws and regulations}

The regency government's understanding of the apparatus regarding the laws and regulations relating to coastal rehabilitation policies has the ability to encourage efforts to unify perceptions and build joint commitment among OPDs. However, the results showed this knowledge is in a low category based on a score range of $1.33-2.00$ with an average of 1.66 as shown in Table 8. This means there is no effective integration of the laws and regulations required to implement the policies among related OPDs, for example, some of the respondents just learned there are rules on the rehabilitation as well as zoning plans for coastal areas and small islands in the province. This means the regency government's policymaking apparatus has not been able to fully understand the problems of the policy to be implemented and this has led to a lack of coordination, especially with the central and provincial governments, thereby making synchronization very difficult.

Table 8. Knowledge of relevant laws and regulations

\begin{tabular}{|c|c|c|c|c|}
\hline \multirow{2}{*}{ No. } & \multirow{2}{*}{ Related laws and regulations } & \multicolumn{3}{|c|}{ Knowledge level (\%) } \\
\hline & & High & Moderate & Low \\
\hline 1. & $\begin{array}{l}\text { Law No. } 32 \text { of } 2009 \text { concerning Environmental Protection } \\
\text { and Management }\end{array}$ & 0 & 50 & 50 \\
\hline 2. & $\begin{array}{l}\text { Law No. } 1 \text { of } 2014 \text { concerning Management of Coastal } \\
\text { Areas and Small Islands }\end{array}$ & 20 & 40 & 40 \\
\hline 3. & Law No. 23 of 2014 concerning Regional Government & 20 & 80 & 0 \\
\hline 4. & Law No. 24 of 2007 concerning Disaster Management & 0 & 20 & 80 \\
\hline 5. & Law No. 26 of 2007 concerning Spatial Planning & 20 & 70 & 10 \\
\hline 6. & $\begin{array}{l}\text { Presidential Regulation No. } 121 \text { of } 2012 \text { concerning the } \\
\text { Rehabilitation of Coastal Areas and Small Islands }\end{array}$ & 0 & 20 & 80 \\
\hline 7. & $\begin{array}{l}\text { Presidential Regulation No.51 of } 2016 \text { concerning } \\
\text { Coastal Boundary }\end{array}$ & 0 & 30 & 70 \\
\hline 8. & $\begin{array}{l}\text { Regional Regulation No. } 5 \text { of } 2019 \text { concerning Zoning } \\
\text { Plans for Coastal Areas and Small Islands of West Java } \\
\text { Province 2019-2039 }\end{array}$ & 0 & 30 & 70 \\
\hline 9. & $\begin{array}{l}\text { Regional Regulation No. } 2 \text { of } 2013 \text { concerning Karawang } \\
\text { Regency Spatial Planning 2011-2031 }\end{array}$ & 30 & 70 & 0 \\
\hline
\end{tabular}




\section{Coastal development orientation}

Development strategies based on economic growth without any reference to natural resources and environmental conditions are not sustainable. Therefore, it is necessary to integrate environmental aspects into development programs (Salim, 2010). It was, however, discovered that the efforts to develop the coastal region of Karawang Regency were oriented towards the economic aspect as observed from the score range of 1.00 3.00 with an average of 2.25 shown in Table 9. This means less attention is paid to the sustainable management of natural resources and environment and this has led to degradation, both in terms of quality and quantity, and also aids disasters. Moreover, the conversion of mangrove forests in the coastal area into fishponds and settlements is one of the causes of erosion considering the ecological role of these forests as a coastline stabilizer (Rezende, Kahn, Passareli \& Vásquez, 2015). As a response to the prevailing disaster in the area, the government initiated a beach rehabilitation policy through the strategic plan of the related Regional Apparatus Organizations for the 2016-2021 period. It included a superior program to handle coastal and estuary erosion through the Public Works and Spatial Planning Office in addition to the management and rehabilitation of coastal and marine ecosystems as well as the protection and conservation of natural resources and living environment by the Environment and Hygiene Office.

Table 9. Coastal area development orientation

\begin{tabular}{clrrr}
\hline \multirow{2}{*}{ No. } & \multicolumn{1}{c}{ Orientation } & \multicolumn{3}{c}{ Orientation aspect (\%) } \\
\cline { 2 - 5 } & Ecology & Economy & Political \\
\hline 1. & Orientation in the development of coastal areas & 40 & 50 & 10 \\
& generally & 30 & 60 & 10 \\
\hline
\end{tabular}

It was also found that there are rare discussions on coastal rehabilitation policies during environmental management coordination meetings of the regency government. This was allegedly due to the non-centrality of the coastal erosion in comparison to other environmental damaging issues such as the impact of oil pollution in the coastal environment and waste pollution in the Citarum Watershed.

Immediate rescue actions were provided for oil pollution because it covers a wider area and its negative impact affects the livelihoods of coastal communities and natural sustainability by decreasing the quantity of fishes, causing crop failure in aquaculture, cessation of tourism activities, and damaging the marine ecosystems, beaches, and mangroves. Moreover, the Citarum River ecosystem is currently being intensively improved by the provincial government through the Citarum Harum program, which is strongly supported by the central government based on the enactment of Presidential Regulation No. 15 of 2018 on Acceleration of Pollution and Damage Control in the Citarum Watershed, which was subsequently followed up by Governor Regulation No. 28 of 2019 on the Action Plan for the Acceleration of Pollution and Damage Control in the Citarum Watershed. However, the results obtained from interviews showed the development of the coastal areas, generally in rural settings, is not a priority due to the focus of the government on urban areas with great potential to improve economic growth. The orientation of the development of coastal areas prioritizes economic aspects also occurred in Natuna Regency (Efina, 2018). The Natuna Regency Government had not yet regulated the activity of mining sand beaches and rocks on Midai Island.

\section{Alignments to coastal rehabilitation policies}

The partiality of the Karawang Regency Government in implementing the coastal rehabilitation policy was found to be in the medium category based on a score of 1.50 - 
3.00 with an average of 2.23 . This is also attached to the low government's desire to understand the problem of coastal erosion and its impact on the community and environment as shown in Table 10. In agreement with these findings, Hogwood \& Gunn (1986) reported non-implementation due to the inability of the parties involved to fully master the problems to be one of the major challenges of public policy implementation apart from the lack of coordination.

Table 10. Alignment with coastal rehabilitation policies

\begin{tabular}{clcrr}
\hline \multirow{2}{*}{ No. } & \multicolumn{1}{c}{ Alignment about } & \multicolumn{2}{c}{ Level of alignments (\%) } \\
\cline { 2 - 4 } 1. & $\begin{array}{l}\text { The urgency of implementing coastal } \\
\text { rehabilitation policies }\end{array}$ & Moderate & Low \\
2. $\begin{array}{l}\text { The desire of the regency government to } \\
\text { implement a coastal rehabilitation policy } \\
\text { The desire of the regency government to } \\
\text { understand the problems of coastal erosion and } \\
\text { their impact on society and the environment }\end{array}$ & 30 & 50 & 10 \\
4. $\begin{array}{l}\text { Understanding the objectives of coastal } \\
\text { rehabilitation policies to improve the welfare of } \\
\text { coastal communities }\end{array}$ & 20 & 50 & 30 \\
\hline
\end{tabular}

The concern of the majority of Bengkalis Regency Government OPDs in implementing coastal rehabilitation policies was also still lacking (Hidayat \& Asrida, 2014). The Maritime Affairs and Fisheries Office and the Environment Agency had initiated the formation of a Regional Mangrove Working Group (KKMD). However, the initiation did not get an adequate response from other OPDs.

\section{Ability to solve problems}

The ability of the Karawang Regency Government to solve problems regarding coastal rehabilitation policies was generally indicated by the facilitation and supervision efforts in accordance with Febriani (2012) and this was found to be at a low level based on the score range of $1.20-2.80$ with an average of 1.64 . This was observed to be due to the limited budget.

For example, the government does not have the capability to compile scientific studies and manage human resources in the field of oceanography because the financial burden required exceeds its budget. This was further exacerbated by the inhibition of ideas related to coastal erosion control from the staff in different related OPDs. Moreover, even though the government has succeeded in compiling a DED research to plan the construction of coastal protection structures, this effort is not enough. Therefore, there is a need for research-based policies for effective disaster management through the contributions of experts and adequate interaction among stakeholders.

Table 11. The intensity of problem solving activities for supporting coastal rehabilitation policies

\begin{tabular}{clrrr}
\hline \multirow{2}{*}{ No. } & \multicolumn{1}{c}{ Activities } & \multicolumn{3}{c}{ Activity intensity (\%) } \\
\cline { 3 - 5 } & & Often & Rare & Never \\
\hline 1. & Preparation of scientific studies & 10 & 20 & 70 \\
2. & Innovation development & 30 & 50 & 20 \\
3. & Comparative study activities & 0 & 30 & 70 \\
4. & Consultation with experts & 10 & 0 & 90 \\
5. & Law enforcement & 30 & 60 & 10 \\
\hline
\end{tabular}


It was discovered that there has never been any activity towards the preparation or conduct of scientific studies based on the concept of research-based policy by consulting experts related to coastal rehabilitation policies as shown in Table 11. This was, however, associated with budget constraints as well as a lack of coordination and interaction among stakeholders in the Karawang Regency Government.

In general, the capacity of the Karawang Regency Government was still low in supporting the successful implementation of coastal rehabilitation policies. It indicated that the low capacity of the Karawang Regency Government causes the low effectiveness of the implementation of coastal rehabilitation policies (Figure 3). This condition results in the low effectiveness of coastal erosion control as a whole, which was characterized by ongoing coastal erosion until today and was a long-standing problem. Ineffective coastal erosion control is one of the factors driving the decline in community welfare in the coastal area of Karawang Regency.

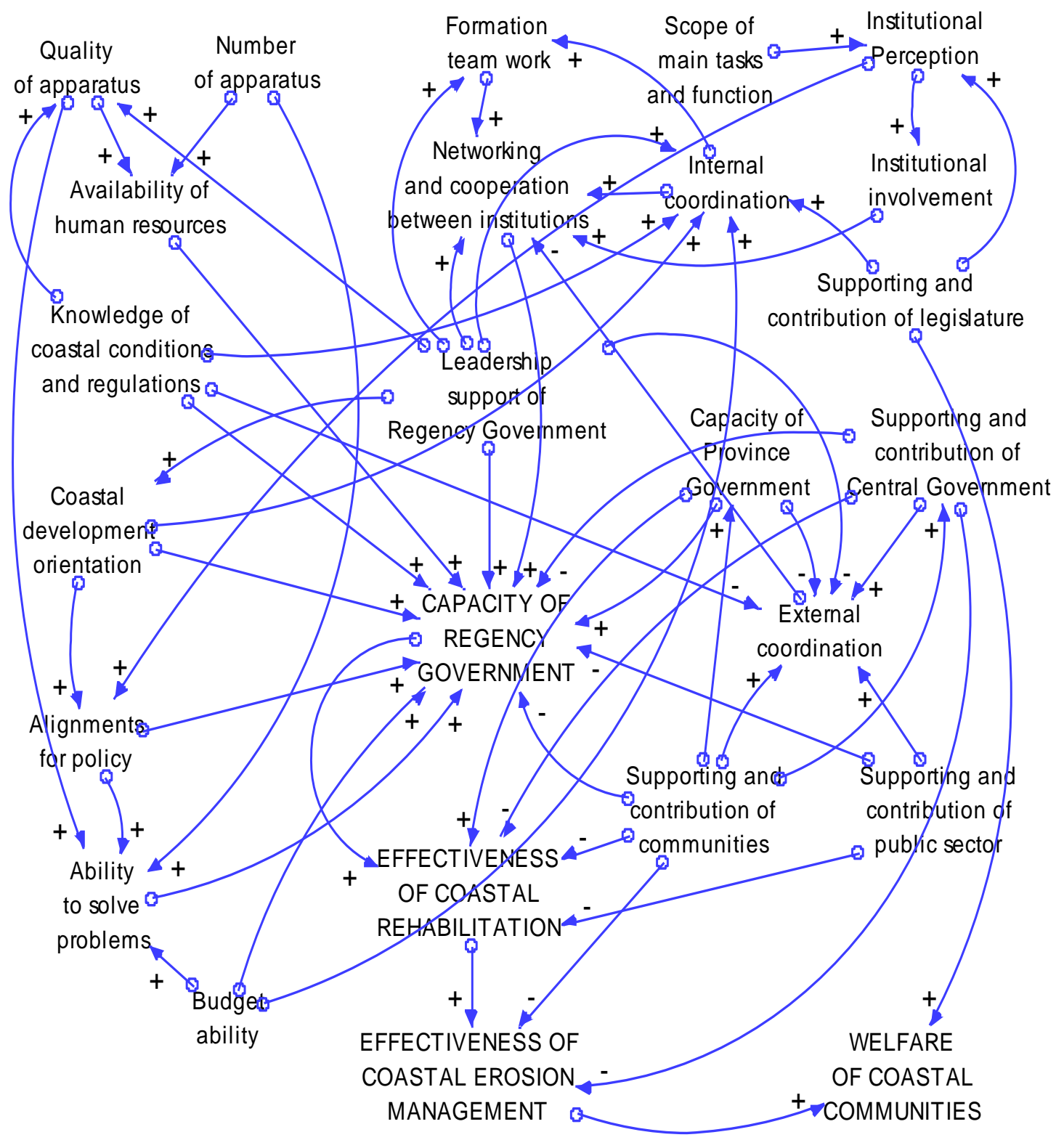

Figure 3. Causal loop diagram of coastal rehabilitation implementation in the coastal region of Karawang Regency 


\section{CONCLUSION AND RECOMMENDATION}

\section{Conclusion}

The capacity of the Karawang Regency Government was still low in supporting the successful implementation of coastal rehabilitation policies. It was indicated various reasons. The availability of human resources to support rehabilitation policies in the Karawang Regency Government was inadequate, both in terms of quantity and quality while the involvement of other Regional Apparatus Organizations and legislature was rare and relatively moderate. Moreover, the regency government's internal coordination support was relatively low while external institutional support was in the moderate category.

The knowledge of the coastal environment condition was in the high category while the respondents' disposition to the laws and regulations related to coastal rehabilitation policies was low. Furthermore, the development of the coastal region was found to be oriented towards the economic aspect while the partiality of the government towards policy implementation was in the moderate category. The ability to solve problems in support of the policies was also found to be low.

\section{Recommendation}

The Karawang Regency Government needs to collaborate with other stakeholders such as universities and several research institutions, at central and regional levels, through the use of different funding schemes to improve the ability to solve problems. Moreover, legislations related to coastal rehabilitation policies should be enhanced by the Legal Section of the Regional Secretariat to establish partnerships with universities in community service activities. The legislature should also support the implementation of these policies through budget alignments while redistribution of employees should be adopted to solve the problem of limited human resources. Furthermore, it is necessary to encourage increased education and training for staff with backgrounds in marine science, oceanography, and other related sciences, through the facilitation of scholarship programs and others.

\section{REFERENCES}

Adhayanto, O., \& Adiputra, Y.S. (2017). Dampak Undang-undang Nomor 23 Tahun 2014 terhadap Peraturan Daerah di Kabupaten Bintan Tahun 2015: Studi Peralihan Kewenangan di Bidang Kelautan dan Pertambangan. Jurnal Selat, 2 (2), 296314.

Alwi, I. (2012). Kriteria Empirik dalam Menentukan Ukuran Sampel pada Pengujian Hipotesis Statistika dan Analisis Butir. Jurnal Formatif, 2(2), 140-148.

Bachtiar, B., \& Hans, A. (2016). Kewenangan Pemerintah Daerah dalam Urusan Kelautan dan Perikanan: Content Analysis terhadap Undang-undang Nomor 23 Tahun 2014 dan Perpu Nomor 2 Tahun 2014. Jurnal Analisis Kebijakan dan Pelayanan Publik, 2(2), 98-110.

Cahyadinata, I., Fahrudin, A., Sulistiono, \& Kurnia, R. (2019). Perception and Participation of Fishermen in The Sustainable Management of Mud Crabs on The 
Outermost Small Island (Case Study: Enggano Island, Bengkulu Province, Indonesia). International Journal on Advanced Science Engineering Information Technology, 9(4), 1330-1336.

Damayanti, R.S. (2016). Pelaksanaan Pengembangan Kapasitas melalui Kerja Sama Pemerintah Provinsi Jawa Timur dan Korea International Cooperation Agency sebagai Upaya Reformasi Birokrasi: Studi pada Lingkup Pemerintah Provinsi Jawa Timur. Jurnal Administrasi Publik, 4(3).

Dapu, Y.M. (2016). Implikasi Undang-undang Nomor 23 Tahun 2014 terhadap Kewenangan Urusan Pemerintahan Daerah di Bidang Kelautan dan Perikanan. Lex et Societatis, 4(8), 68-75.

Dewanti, M.A.M., Sarwono, \& Makmur, M. (2013). Kapasitas Pemerintah Kota Batu dalam Program Pelayanan Kesehatan bagi Masyarakat Miskin. Jurnal Administrasi Publik, 1(5), 900-909.

[DCK Kab. Karawang] Dinas Cipta Karya Kabupaten Karawang. (2017). Rencana Program Investasi Jangka Menengah (RPIJM) Kabupaten Karawang Tahun 20172022. Available at: http://sippa.ciptakarya.pu.go.id/sippa_online/ws_file/dokumen/ rpi2jm/DOCRPIJM_8aed426f2a_BAB\%20IIBab\%202\%20Profil\%20Kabupaten $\%$ 20Karawang.pdf.

Djelantik, A.A.G.M.S.W, Sumerthayasa, P.G.A, \& Suharta, N. (2016). Implikasi Yuridis dengan Diundangkannya Undang-undang Nomor 23 Tahun 2014 tentang Pemerintahan Daerah terhadap Kewenangan Pengelolaan Laut, Pesisir, dan PulauPulau Kecil. Kertha Negara, (4)1, 1-5.

[DLHK Kab. Karawang] Dinas Lingkungan Hidup dan Kebersihan Kabupaten Karawang. (2018). Laporan Akuntabilitas Kinerja Instansi Pemerintah Dinas Lingkungan Hidup dan Kebersihan Kabupaten Karawang Tahun 2018. Available at: https://karawangkab.go.id/dokumen/laporan-akuntabilitas-kinerja-instanssipemerintah-lakip-tahun-2018-dlhk.

[DPRKP Kab. Karawang] Dinas Perumahan Rakyat dan Kawasan Pemukiman Kabupaten Karawang. (2018). Laporan Akuntabilitas Kinerja Instansi Pemerintah Dinas Perumahan Rakyat dan Kawasan Pemukiman Kabupaten Karawang Tahun 2018. Available at: https://karawangkab.go.id/dokumen/laporan-akuntabilitaskinerja-lakip-tahun-2018-dprkp.

[DPUPR Kab. Karawang] Dinas Pekerjaan Umum dan Penataan Ruang Kabupaten Karawang. (2016). Program/Kegiatan Unggulan Rencana Strategis Dinas Bina Marga dan Pengairan Kabupaten Karawang Tahun 2016-2020. Available at: https://karawangkab.go.id/dokumen/program-unggulan-dinas-pekerjaan-umumdan-penataan-ruang.

Dunn, W.N. (2003). Public Policy Analysis: An Introduction. New Jersey (US): PrenticeHall Inc.

Efina, K. (2018). Kebijakan Pemerintah Kabupaten Natuna terhadap pencegahan abrasi pantai di Pulau Midai tahun 2017. Available at: http://repository.umrah.ac.id/1204/1/Kurnia\%20Efina-100565201026-FISIP2018.pdf. 
Ekowati, M.R.L. (2009). Perencanaan, Implementasi dan Evaluasi Kebijakan atau Program: Suatu Kajian Teoritis dan Praktis. Jakarta (ID): Pustaka Cakra.

Febriani, D. (2012). Evaluasi Proses Implementasi Kebijakan Hutan Tanaman Rakyat di Kabupaten Sarolangun, Jambi [Doctoral Dissertation, Graduated Program, Institut Pertanian Bogor]. Graduated Program, Insitut Pertanian Bogor. Available at: https://repository.ipb.ac.id/jspui/bitstream/123456789/61111/1/ 2012dfe.pdf

Fauzi, L.M. (2016). Peningkatan Kapasitas Pemerintahan Daerah dalam Proses Masyarakat Ekonomi ASEAN. Jurnal Ilmu Politik dan Komunikasi, 6(2), 6370.

Fauzie, A.K. (2017). Analysis of Short and Medium Term Coastal Abrasion and Accretion Rates using GIS in Karawang, West Java. Creative Research Journal. 3(2), 91-104.

Fitria. (2007). Pengaruh Abrasi di Pantai Grogol Kecamatan Cirebon Utara Kabupaten Cirebon dan Pantai Bojongsalawe Kecamatan Parigi Kabupaten Ciamis terhadap Komponen-komponen Sistem Pembangunan Wilayah Pesisir dan Laut [Master's thesis, Sekolah Arsitektur, Perencanaan dan Pengembangan Kebijakan, Institut Teknologi Bandung]. Sekolah Arsitektur, Perencanaan dan Pengembangan Kebijakan (SAPPK) Institut Teknologi Bandung.

Gay, L.R., Mills, G.E., \& Airasian, P. (2009). Educational Research, Competencies for Analysis and Application. New Jersey (US): Pearson Education, Inc.

Hidayat, R., \& Asrida, W. (2014). Upaya Pemerintah Kabupaten Bengkalis dalam Penanggulangan Abrasi: Studi pada Pesisir Pantai Kabupaten Bengkalis Tahun 2010-2012. JOM FISIP, 1(2), 1-16.

Hogwood, B.W., \& Gunn, L.A. (1986). Policy Analysis for The Real World. New York (US): Oxford University Press.

Iskandar, D., Bukit, R., \& Yahya, I. (2013). Pengaruh Kapasitas Sumber Daya Manusia, Perencanaan Anggaran dan Politik Penganggaran, dengan Transparansi Publik sebagai Variabel Moderating terhadap Sinkronisasi Dokumen APBD dengan Dokumen KUA-PPAS pada Pemerintah Kabupaten Aceh Tenggara. Jurnal Telaah dan Riset Akuntansi, 6(1), 93-108.

Komarudin, R.A. (2013). Model Perubahan Penggunaan Lahan Pesisir untuk Mendukung Rencana Tata Ruang Wilayah Kabupaten Karawang [Master's thesis, Graduated Program, IPB University]. Graduated Program, IPB University. Available at: https://repository.ipb.ac.id/handle/123456789/63511

Marliawati, D. (2013). Pelaksanaan Pengembangan Kapasitas Kelembagaan Pemerintahan Daerah: Studi di Bagian Organisasi Sekretariat Daerah Pemerintah Kabupaten Malang. Jurnal Administrasi Publik, 1(7).

Mu'in, F. (2011). Pendidikan Karakter Konstruksi Teoretik dan Praktik. Yogyakarta (ID): Ar-Ruzz Media.

Mukhlis, M. (2016). Tata Kelola Pemerintahan dalam Peningkatan Kapasitas Adaptif/ketahanan Kota Bandar Lampung terhadap Dampak Perubahan Iklim. Jurnal Ilmu Politik dan Komunikasi, 6(2), 1-16. 
Mutia, K., Roisah, K., \& Supriadhie, K. (2016). Kapasitas Pemerintah Daerah dalam Melakukan Hubungan Luar Negeri menurut Hukum Internasional: Studi Kasus Tindakan Pemerintah Daerah Istimewa Aceh Mengambil Alih Baitul Asyi di Arab Saudi tanpa melalui Hubungan Konsuler RI. Diponegoro Law Review, 5(3), $1-18$.

Nasution, M.E., \& Usman, H. (2008). Proses Penelitian Kuantitatif. Jakarta (ID): Lembaga Penerbit Fakultas Ekonomi Universitas Indonesia.

Nazir, M. 2014. Metode Penelitian. Bogor (ID): Ghalia Indonesia.

Ningtyas, M.R.J., Ribawanto, H., \& Hadi, M. (2014). Upaya Pemerintah Daerah dalam Meningkatkan Kapasitas Kelembagaan: Studi Kasus pada Bagian Organisasi dan Tata Laksana Pemerintah Kota Blitar. Jurnal Administrasi Publik, 2(4), 687693.

[Pemkab. Karawang] Pemerintah Kabupaten Karawang. (2010). Peraturan Daerah Kabupaten Karawang No. 2 Tahun 2010 tentang Rencana Pembangunan Jangka Panjang Daerah (RPJPD) Kabupaten Karawang Tahun 2005-2025. Available at: http://www.karawangkab.go.id/dokumen/rpjpd-2005-2025.

Rezende, C.E., Kahn, J.R., Passareli, L., \& Vásquez, W.F. (2015). An Economic Valuation of Mangrove Restoration in Brazil. Ecological Economics, 120, 296-302.

Rusmilyansari, Rosadi, E., \& Apriansyah. (2014). Kapasitas dan Strategi Kelembagaan Pemerintah dalam Pengelolaan Konflik Antar Pengguna Sumber Daya Perairan Kabupaten Tanah Laut. Marine Fisheries, 5(1), 41-48.

Sahadia, A.S., Komba, S., \& Basri, M. (2019). Reformasi Birokrasi melalui Pengembangan Kapasitas Organisasi Pemerintah Kabupaten Buton Utara. Jurnal Publica, 10(1), 71-80.

Salim, E. (2010). Paradigma Pembangunan Berkelanjutan. Di dalam: Azis, I.J., Napitupulu, L.M., Patunru, A.A., Resosudarmo, B.P., editor. Pembangunan Berkelanjutan: Peran dan Kontribusi Emil Salim. Jakarta (ID): Kepustakaan Populer Gramedia.

Sari, N., Noor, I., \& Prasetyo, W.Y. (2014). Pengembangan Kapasitas Kelembagaan Pemerintah Daerah dalam Meningkatkan Kualitas Pelayanan Perizinan Terpadu: Studi pada Kantor Pelayanan dan Perizinan Terpadu Kabupaten Kediri. Jurnal Administrasi Publik, 2(4), 634-640.

Satria, S.Y., \& Anwar, K. (2018). Kapasitas Pemerintah Daerah Kabupaten Karimun dalam Mengelola Sumber Daya Mineral Pertambangan Granit tahun 2014-2016. JOM FISIP, 5(2): 1-14.

Setianto, N.A. (2016). Qualitative Modelling of The Impact of Government Grant on Beef Cattle Farming Performance. Agripet, 16(2), 114-120.

Sihombing, B. (2010). Studi Potensi Sumber-sumber Pendanaan Peningkatan Kapasitas yang Berkelanjutan pada Pemerintah Kabupaten Tapanuli Tengah. Jurnal Manajemen dan Bisnis, 10(2), 1-24.

Trisnantoro, L. (2011). Pengembangan Kapasitas Kepala Dinas Kesehatan: Apakah Perlu Diperkuat dengan Aturan di Level Peraturan Pemerintah? Jurnal Manajemen Pelayanan Kesehatan, 14(3), 119. 
Triastuti, M.R.H. (2013). Menakar Kapasitas Governance Pemerintah Daerah dalam Memfasilitasi Usaha Kecil dan Menengah. Jurnal Ilmu Administrasi. 10(2), 186198.

Widyahantari, R., \& Rudiarto, I. (2018). Kapasitas Pemerintah Kota Bandung dalam Penyediaan Taman Tematik guna Mewujudkan Kota Layak Huni. Jurnal Pengembangan Kota, 6(1), 9-16.

(C) 2020 by the authors. Licensee JPPD, Indonesia. This article is an open access article distributed under the terms and conditions of the Creative Commons Attribution (CC BY) license (http://creativecommons.org/licenses/by/4.0/). 